Publisher homepage: www.universepg.com, ISSN: 2663-7529 (Online) \& 2663-7510 (Print)

https://doi.org/10.34104/ejmhs.020.21027

European Journal of Medical and Health Sciences

Journal homepage: www.universepgcom/journal/ejmhs

\title{
Boon and Bane of Transgenic Animal: A Brief Review
}

\author{
Chandan Sarkar ${ }^{1}$, Sarmin Jamaddar ${ }^{1}$, Tasniya Nahiyan Zulfiquar ${ }^{1}$, and Milon Mondal ${ }^{1 *}$ \\ ${ }^{1}$ Department of Pharmacy, Bangabandhu Sheikh Mujibur Rahman Science and Technology University, Gopalganj-8100, \\ Bangladesh \\ *Correspondence: milon_mondal@bsmrstu.edu.bd
}

\begin{abstract}
The progression of biotechnology and genetic engineering to produce transgenic animals by familiarizing the foreign DNA into the germ line of an animal has elevated the potential of biological research to an unprecedented level. This technology not only beneficial in human welfare, society and the environment but also harmful. At present, many transgenic species (goats, chickens, pigs, cows, mice, rabbits, sheep, etc.) are considered for research applications as well as latent profitable pharmaceutical productively. Transgenic animals are applied as the different models for the experiment of different diseases including HIV/AIDS, Alzheimer's, Cardiovascular, and Diabetes Mellitus, Angiogenesis, and Cancer disease. The main disadvantages of transgenic animals are mutagenesis and function disorders, ecological problems, antibiotic resistance, and population of clones.
\end{abstract}

Keywords: Transgenic animal, Monoclonal antibodies, Vaccines, Angiogenesis, Boon, Bane, and Cancer.

\section{INTRODUCTION}

A transgenic animal refers to an animal that is altered by the starter of recombinant DNA through human interferences. It relates to the transgenes is that means a technique for insertion of cDNA which is created by specific mRNA (Messenger Ribonucleic Acid) into cells. The techniques applied to create transgenic animal by the direct manipulation of DNA (Gama and Bressan, 2011), (Rossana and Cristina, 2010) also have negative waves on human welfare, society, and environment. The two biologists (Watson and Crick) discovered the DNA in the 1950s and from this time the basic concepts of the transgenic animals by manipulating DNA have come. In early 1980, Gordon et al. first experimented with the gene addition with the aid of technology namely microinjection and from that time a new waywardness was come in genetics and molecular biology research field to drive forward (Bagle et al., 2011). With the aid of various techniques UniversePG I www.universepg.com from cited reports, molecular biology and genetic engineering achieved impetus and the scientists started to develop the animals with some basic concepts. In addition, this technology added new invent in the economy and health sectors to develop the economic qualities and healthful treatments quickly. An example was noted that the transgenic animal (cattle) was prepared to yield a large amount of milk with healthy human proteins that may be used for the treatment of human emphysema and may also be beneficial in economic circumstances (Margawati, 2003).

This study helps by providing positive and negative influences of transgenic animals in society, human welfare, economic situation, environment, and medicinal field that also services the future direction of research on transgenic animal using molecular biology and genetic engineering (Shahen et al., 2019). 


\section{Production of transgenic animals}

Three animal models that are aggressively used in the laboratory to formulate transgenic animals including (1) DNA microinjection, (2) Retrovirus-mediated gene transfer, and (3) cell-mediated gene transfer. Some steps are required to develop a satisfactory transgenic animal in the molecular research field, and these steps are given below and as displayed in Fig 1 (Houdebine, 2009; Fee and Chand, 2005):

Step 1. Identification of the desired gene (DNA) and promoter sequences.

Step 2. The desired gene is then directly hosted into the nucleus of a donor egg by following apt methods.

Step 3. The engineered cells are then implanted into the host animals.

Step 4. Development of the desired cells within the host and able to provide the desired gene that has been stably and heritably incorporated into the newborn offspring's DNA.

Step 5. The gene is then able to continue its function in the new environment.

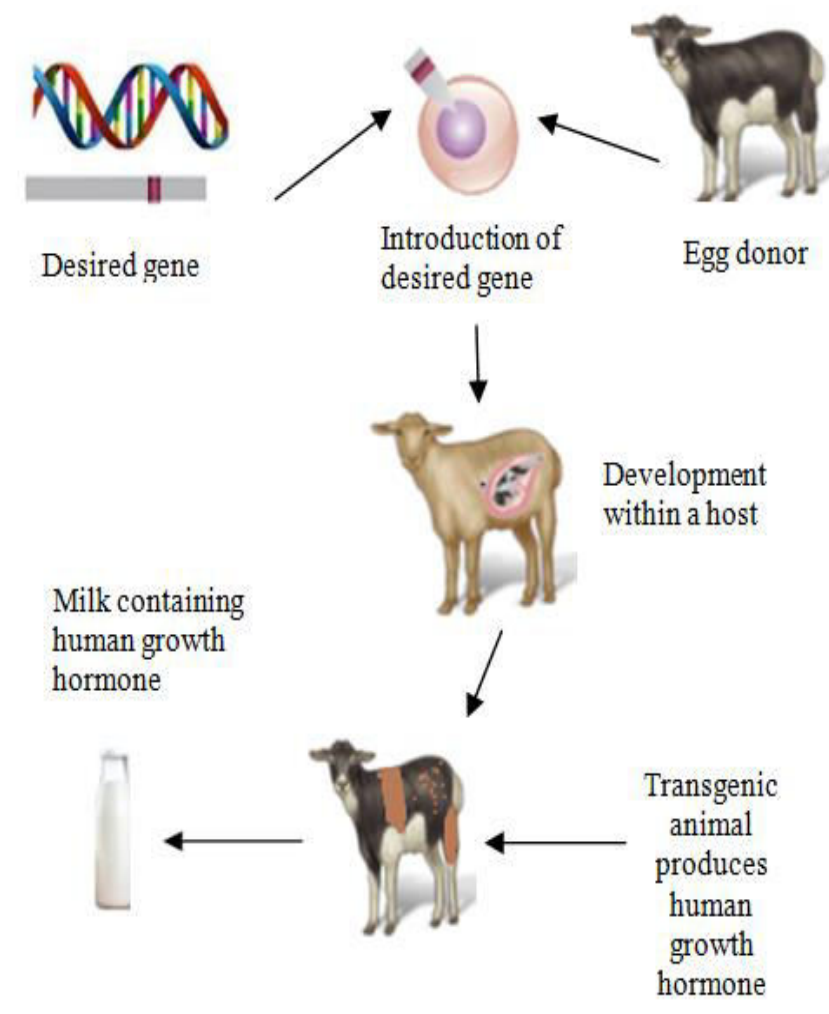

Fig 1: Production of transgenic animal.

\section{TRANSGENIC ANIMALS AND PRODUCTS FROM THEM}

Numerous researches using transgenic species have already done to apply for the development of commercial pharmaceutical product that is displayed as Table 1.

Table 1: Products from transgenic animals

\begin{tabular}{|c|c|c|}
\hline Animals & Products & References \\
\hline Goats & $\begin{array}{l}\text { Monoclonal Antibodies } \\
\text { (MAbs), Ig fusion proteins, } \\
\text { tPA (tissue Plasminogen } \\
\text { Activator) and ATryn } \\
\text { (recombinant human } \\
\text { antithrombin III). }\end{array}$ & $\begin{array}{l}\text { Fee and } \\
\text { Chand, } \\
\text { 2005; and } \\
\text { Ormandy et } \\
\text { al., } 2011\end{array}$ \\
\hline $\begin{array}{l}\text { Chickens } \\
\text { and Eggs }\end{array}$ & $\begin{array}{l}\text { Vaccines; interferons, } \\
\text { cytokines; Human Serum } \\
\text { Albumin, insulin, MAbs. }\end{array}$ & $\begin{array}{l}\text { Ormandy et } \\
\text { al., } 2011\end{array}$ \\
\hline Pigs & $\begin{array}{l}\text { Organs for } \\
\text { xenotransplantation, human } \\
\text { hemoglobin, human protein C. }\end{array}$ & $\begin{array}{l}\text { Prather } \text { et } \\
\text { al., 2008; } \\
\text { and Hunter } \\
\text { et al., } 2005\end{array}$ \\
\hline Cows & $\begin{array}{l}\text { Factors VIII and IX, protein } \\
\text { C, recombinant antithrombin } \\
\text { III (rATIII), rHSA, and } \\
\text { human milk protein. }\end{array}$ & $\begin{array}{l}\text { Ormandy et } \\
\text { al., } 2011\end{array}$ \\
\hline Mice & $\begin{array}{l}\text { Expression of malaria protein } \\
\text { for vaccine development; } \\
\text { MAbs, ATIII, beta interferon; } \\
\text { cystic fibrosis transmembrane } \\
\text { regulator; Factor X, HSA, } \\
\text { tPA, myelin basic protein; } \\
\text { prolactin; fibrinogen and } \\
\text { antineoplastic urinary protein. }\end{array}$ & $\begin{array}{l}\text { Ormandy et } \\
\text { al., } 2011\end{array}$ \\
\hline Rabbits & $\begin{array}{l}\text { Recombinant human } \mathrm{C} 1 \\
\text { inhibitor, human } \\
\text { erythropoietin, human alpha } \\
\text { antitrypsin, human interleukin } \\
2 \text {, tPA, alpha glucosidase, and } \\
\text { human growth hormone. }\end{array}$ & $\begin{array}{l}\text { Ormandy et } \\
\text { al., } 2011\end{array}$ \\
\hline Sheep & $\begin{array}{l}\text { Sheep milk includes } \\
\text { fibrinogen (major constituent, } \\
\text { with thrombin and Factor } \\
\text { XIII) human Factor VII, } \\
\text { Factor IX, activated protein C } \\
\text { and alpha-1-antitrypsin. }\end{array}$ & $\begin{array}{l}\text { Ormandy et } \\
\text { al., 2011; } \\
\text { and Hunter } \\
\text { et al., } 2005\end{array}$ \\
\hline
\end{tabular}

UniversePG I www.universepg.com 
TRANSGENIC ANIMAL MODELS OF ASSORTED DISEASES

An animal model may be a living, a non-human animal used for research and investigation of human disease, for the aim of higher understanding the disease without the added risk of causing harm to a person's being during the whole drug discovery and development process. There are different models of transgenic animals for various diseases.

Table 2: The transgenic animal models of various diseases

\begin{tabular}{|c|c|c|}
\hline Disease & Models & References \\
\hline HIV/AIDS & $\begin{array}{l}\text { Tg26 HIVAN Mouse Model and } 32 \text { transgenic murine HIVAN models } \\
\text { are developed that can express HIV-1 proteins. }\end{array}$ & $\begin{array}{l}\text { Rosenstiel } \text { et al., 2009; } \\
\text { Joshi and Guidot, } 2011\end{array}$ \\
\hline $\begin{array}{l}\text { Alzheimer's } \\
\text { disease }\end{array}$ & $\begin{array}{l}\text { Amyloid pathology mouse models like PDAPP mice, Tg2576 mice, } \\
\text { TAU transgenic mouse models like ALZ7 mice, } 7 \text { TauTg mice and } \\
\text { presenilin transgenic models like ApoE knockout. }\end{array}$ & $\begin{array}{l}\text { Spires and Hyman, 2005; } \\
\text { Schenk, 2002; and Götz } \\
\text { et al., } 2014\end{array}$ \\
\hline $\begin{array}{l}\text { Cardiovascular } \\
\quad \text { disease }\end{array}$ & $\begin{array}{l}\text { Transgenic models of heart failure and hypertrophy like Gene over } \\
\text { expression of Calmodulin, Gene mutation of alpha cardiac myosin } \\
\text { heavy chain, Knockout and mutation of the ApoE gene model of } \\
\text { transforming growth factor are developed. }\end{array}$ & $\begin{array}{l}\text { Snaith, and Törnell, 2002; } \\
\text { and Bader } \text { et al., } 2000\end{array}$ \\
\hline $\begin{array}{l}\text { Diabetes } \\
\text { Mellitus }\end{array}$ & $\begin{array}{l}\text { Models of insulin secretion such as glucokinase, islet amyloid } \\
\text { polypeptide, and hepatic glucose production in type } 2 \text { diabetes are } \\
\text { developed. Beta receptor knockout mouse, uncoupling protein (UCP1) } \\
\text { knockout mouse, acute and chronic models for the evaluation of anti- } \\
\text { diabetic agents. }\end{array}$ & $\begin{array}{l}\text { Srinivasan and Ramarao, } \\
\text { 2007; Etuk, 2010; Henson } \\
\text { and O'Brien 2006; and } \\
\text { Kumar } \text { et al., 2012 }\end{array}$ \\
\hline Angiogenesis & $\begin{array}{l}\text { Mouse models of angiogenesis, arterial stenosis, atherosclerosis, } \\
\text { thrombosis, thrombolysis and bleeding addresses techniques to } \\
\text { evaluate vascular development. }\end{array}$ & Snaith and Törnell 2002 \\
\hline $\begin{array}{l}\text { Cancer } \\
\text { diseases }\end{array}$ & $\begin{array}{l}\text { Transgenic knockout models like tumor progression and metastasis via } \\
\text { E-cadherin. LACI transgenic model and LACZ transgenic model for } \\
\text { mutagenicity assays. Transgenic rodent models expressing tumor } \\
\text { associated antigens like MUC1 transgenic mice, oncogene transgenic } \\
\text { mice use in immunotherapeutic strategies. Preclinical transgenic model } \\
\text { of Matrix Metalloproteinase (MMP) inhibitors studies. }\end{array}$ & $\begin{array}{l}\text { Bagle et al., 2011; } \\
\text { Pavlaki and Zucker, } \\
\text { 2003; and Ramaswamy et } \\
\text { al., } 2007\end{array}$ \\
\hline
\end{tabular}

\section{ADVANTAGES OF TRANSGENIC ANIMALS}

Transgenic animals contribute to human welfare. These animals can cause beneficial effect of human in the field of agriculture, medicine and industry.

\section{A. Agricultural}

Breeding: Propagation by the traditional way is a time consuming and difficult task. During developing molecular biology technology, developing traits in animals became feasible in a shorter time and with more exactitude. Furthermore, the farmer can get an undemanding way to increase yields (Lee et al., 1997)
Quality: Transgenic cows can produce more milk. They can also produce milk with less lactose or cholesterol. Transgenic pigs and cattle contain more meat on them and in the case of transgenic sheep; they cultivate more wool (Wheeler, 2007).

Disease resistance: According to scientist effort, disease resistant animals are being tried to produce like influenza resistant pigs, whereas a very limited number of genes are at this time known to be accountable for resistance to diseases in farm animals (Margawati, 2003). 


\section{B. Medical}

Xenotransplantation: Because of the in need of a replacement heart, liver or kidney, an enormous number of patient die, where transgenic pigs may offer the transplant organs to beat the matter of shortfall (Hoagland et al., 1997). Currently, a pig protein hinders xenotransplantation. This protein may originate contributor rejection. However research is ongoing to get rid of that pig protein and substitute it with a person's protein.

\section{Nutritional supplements and pharmaceuticals:} Some products for instance insulin, somatotropin, and blood anti-clotting factors may during a few minutes be or have by now been obtained from the milk of transgenic cows, sheep, or goats (Gunawan and Noor, 2006; and Islam et al., 2020).

Human gene therapy: In human gene therapy, a traditional copy of a gene which will be transgenic is added to the genome of an individual who carries defective replicas of the gene. For instance, the A. I. Virtanen Institute in Finland produced a calf with a gene that creates the substance that promotes the expansion of red cells in humans.

Industrial: In the year of 2001, two scientists at Nexia Biotechnologies in Canada researched with spider genes and goats. They spliced spider genes into the cells of lactating goats. Then the goats commenced to manufacture not only silk along with their milk but also exude tiny silk strands from their body by the bucketful. When the polymer strands from the milk is extracted and weaved them into thread, the scientists can generate a light, tough, flexible material that could be used in such applications as military uniforms, medical micro-sutures, and tennis racket strings (Pust, 2010). Transgenic animals are toxicity-sensitive that are also created for testing chemical safety (Sharif et al., 2019).

A wide range microorganism is engineered to supply a good sort of proteins, which successively can produce enzymes and these enzymes are often wont to speed up chemical reactions in several sorts of industries (Margawati, 2003; Alam et al., 2017).

\section{DISADVANTAGES OF TRANSGENIC ANIMALS}

Accidental damage or reproduction problems: Transgenic animals usually have shorter life spans and their survival rates also are low. However, an unexpected problem may arise within the time of mixing different species as at that case, thousands of genes would be interacting, not only one or two genetic elements of importance (Wessells, 2009).

Mutagenesis and function disorders: Within the time of production of transgenic animals, genetic mutations can occur which can end in diseases and disorders. Besides, mutagenesis can interrupt normal development or cause a medical circumstance. A situation caused by mutations in one or more genes is named a genetic disease (Oliver and Davies, 2005).

Expensive and extensive: The value of kit and animals is high. Also, it takes a short time to seek out the proper thanks to genetically modify the animal for whatever purpose. It doesn't happen overnight (Grandin and Johnson, 2009).

Unintended adverse effects: Genes have quite one function. A gene in one animal may function certain activities or not that the opposite one doesn't. This may cause problems within the genes that can't fully perform their function (Pahsini et al., 2016).

Nature is complex: Nature is a particularly complex inter-dependent chain consisting of the many species linked during an organic phenomenon. Genetically modifying animals may have unalterable effects with unknown consequences (Islam and Islam, 2014).

Effects on the environment: Ecological complexes may be created through the newly produced transgenic animals by gene-splicing. The discharge of a brand new genetically concocted species would even have the likelihood of causing an imbalance within the ecology of a neighborhood just exotic species would do. An accident or an unknown result could cause several problems (Mercer et al., 1999).

Effects on human: If we observe at the very fact that transgenic animal services viral vector that carries 
functional gene secret the physical body, the repercussion remains unknown. There's no evidence on where functional genes are being placed. They'll even switch the important genes, in its place of mutated genes (Patra and Andrew, 2015). Thus, this might cause another health condition or disease to humans.

Antibiotic resistance: In transgenic animals, the genes are used for antibiotic resistance as "selectable markers." In the gene-splicing process, these markers helped identify cells that have haunted foreign genes. Without further experiments, the genes are still being expressed in animal tissues. The resistance genes could be transported to human or animal pathogens, creating them resistant to antibiotics (Rahman et al., 2019). If genes needed to be transferred, it could exacerbate the intense unhealthiness of antibioticresistant disease organisms (Mepham, 2000).

The population of clones: The transgenic animals are a population of clones, vulnerable in very same ways. One disease or pest can wipe out the whole population quickly (Stewart, 2004).

Ethical issues: Transgene use in humans is currently fraught with issues. The transformation of genes into human cells has not been perfected yet. A crucial example is-patients developing T-cell leukemia after being treated with $\mathrm{X}$-linked severe combined immunodeficiency (X-SCID) (Woods et al., 2006). This was attributed to the close proximity of the inserted gene to the LMO2 promoter, which controls the transcription of the LMO2 proto-oncogene (Hacein-Bey-Abina et al., 2003). In short, within the most sort of gene-splicing, the utilization of transgenes for purposes aside from to correct life-threatening genetic abnormalities may be a major bioethical issue.

\section{CONCLUSION}

The science is updated gradually and produces alternative of the naturally occurring foods and animals for various beneficial purposes but uncertainly the values of nature are diminishing gradually. This review summarizes the production of transgenic animals with their boon and bane in agriculture, medical, economy, and environment. Different types of species especially goats, chickens, pigs, cows, mice, rabbits, sheep, etc. are used to prepare models of transgenic animals for different beneficial events, but they may also provide some negative impact on human welfare. In a nutshell, this work opens new avenues for the transgenic animals to be used as a model of events may arises complications with their delighted beneficial effects.

\section{ACKNOWLEDGMENT}

The authors would like to express their thanks to the Department of Pharmacy, Bangabandhu Sheikh Mujibur Rahman Science and Technology University, Gopalganj 8100, Bangladesh

\section{CONFLICT OF INTEREST}

The authors declare that they have no competing conflict of interests to publish under current issue of the journal.

\section{REFERENCES}

1. Alam Md. Gahangir, Md. Ekhlas Uddin, Sezanur Rahman, Tasnim Ahmad, Pulak Maitra, (2017). Protease activity of the extracellular enzyme produced by $B$. subtilis isolated from soil. International J. of Environment, Agriculture and Biotechnology. 2(1), 382-388.

https://doi.org/10.22161/ijeab/2.1.48

2. Bader, M., Zollmann, F.S., Lockley-Jones, O.E. and Ganten, D., (2000). Transgenic animals in cardiovascular disease research. Experimental physiology, 85(6), 713-731.

3. Bagle, T.R., Baig, M.S. and More, S.Y., (2013). Transgenic animals and their application in medicine. International J. of Medical Research \& Health Sciences, 1(2), 107-116.

4. Etuk, E.U., (2010). Animals models for studying diabetes mellitus. Agric Biol JN Am, 1(2), 130134.

5. Fee, C.J. and Chand, A., (2005). Design considerations for the batch capture of proteins from raw whole milk by ion exchange chromatography. Chemical Engineering \&

UniversePG I www.universepg.com 
Technology: Industrial Chemistry Plant Equipment Process Engineering Biotechnology, 28(11), 1360-1366.

6. Gama, L.T. and Bressan, M.C., (2011). Biotechnology applications for the sustainable management of goat genetic resources. Small Ruminant Research, 98(1-3), 133-146.

7. Götz, J., Streffer, J.R., David, D., Schild, A., Hoerndli, F., and Chen, F., (2004). Transgenic animal models of Alzheimer's disease and related disorders: histopathology, behavior and therapy. Molecular psychiatry, 9(7), 664-683.

8. Grandin, T. and Johnson, C., (2009). Animals in translation: Using the mysteries of autism to decode animal behavior. SUNY Press.

9. Gunawan, A. and Noor, R.R., (2006). Pendugaan nilai heritabilitas bobot lahir dan bobot sapih domba Garut tipe laga. Media Peternakan, 29(1), 7-15.

10. Hacein-Bey-Abina, S., Von Kalle, C., Schmidt, M., Morillon, E. and Sorensen, R., (2003). LMO2associated clonal $\mathrm{T}$ cell proliferation in two patients after gene therapy for SCIDX1. Science, 302(5644), 415-419.

11. Henson, M.S. and O'Brien, T.D., (2006). Feline models of type 2 diabetes mellitus. ILAR journal, 47(3), 234-242.

12. Hoagland, T.A., Julian, M., Riesen, J.W., Schrieber, D. and Fodor, W.L., (1997). Transgenic pigs as animal models for xenogenic transplantation. Theriogenology, 1(47), 224.

13. Houdebine, L.M., (2009). Production of pharmaceutical proteins by transgenic animals. Comparative immunology, microbiology and infectious diseases, 32(2), 107-121.

14. Hunter, C.V., Tiley, L.S. and Sang, H.M., (2005). Developments in transgenic technology: applications for medicine. Trends in molecular medicine, 11(6), 293-298.

15. Islam, R., Alam, Md. K., Uddin, Md. E., Imran, Md. A. S., and Alam, Md. F. (2020). Antibacterial Activity of Lactic Acid Bacteria and Extraction of Bacteriocin Protein. Advances in Bioscience and Biotechnology, 11, 49-59. https://doi.org/10.4236/abb.2020.112004
16. Islam, S. and Islam, S., (2014). The perceived impression of public on Genetic Engineering. Northern International Medical College Journal, 6(1), 32-35.

17. Joshi, P.C. and Guidot, D.M., (2011). HIV-1 transgene expression in rats induces differential expression of tumor necrosis factor alpha and zinc transporters in the liver and the lung. AIDS research and therapy, $\mathbf{8}(1), 36$.

18. Kumar, S., Singh, R., Vasudeva, N. and Sharma, S., (2012). Acute and chronic animal models for the evaluation of anti-diabetic agents. Cardiovascular diabetology, 11(1), 9.

19. Lee, C.S., Choi, Y.H., Oh, K.B., Kang, Y.K. and Lee, K.K., (1997). Temporal-and spatial-specific expression of bovine $\beta$-casein/bovine growth hormone fusion gene in transgenic mice. Theriogenology, 1(47), 225.

20. Mepham, T.B., (2000). The role of food ethics in food policy. Proceedings of the Nutrition Society, 59(4), 609-618.

21. Mercer, D.K., Bruce-Johnson, W.A., Glover, L.A. and Flint, H.J., (1999). Fate of free DNA and transformation of the oral bacterium Streptococcus gordonii DL1 by plasmid DNA in human saliva. Appl. Environ. Microbiol. 65(1), 6-10.

22. Margawati, E.T., (2003). Transgenic animals: Their benefits to human welfare. American Institute for Biological Sciences, 1-6.

23. Oliver, P.L. and Davies, K.E., (2005). Analysis of human neurological disorders using mutagenesis in the mouse. Clinical Science, 108(5), 385-397.

24. Ormandy, E.H., Dale, J. and Griffin, G., (2011). Genetic engineering of animals: ethical issues, including welfare concerns. The Canadian Veterinary Journal, 52(5), 544.

25. Pahsini, K., Marinschek, S., Khan, Z., DunitzScheer, M. and Scheer, P.J., (2016). Unintended adverse effects of enteral nutrition support: parental perspective. Journal of pediatric gastroenterology and nutrition, 62(1), 169-173.

26. Patra, S. and Andrew, A.A., (2015). Human, Social, and Environmental Impacts of Human Genet. J. of Biomedical Sciences, 4:2, 1-3. 
27. Pavlaki, M. and Zucker, S., (2003). Matrix metalloproteinase inhibitors (MMPIs): the beginning of phase I or the termination of phase III clinical trials. Cancer and metastasis reviews, 22(2-3), 177-203.

28. Prather, R.S., Shen, M. and Dai, Y., (2008). Genetically modified pigs for medicine and agriculture. Biotechnology and Genetic Engineering Reviews, 25(1), 245-266.

29. Pust A, D., (2010). Animal Transgenesis and its Applications: Bulletin of University of Agricultural Sciences and Veterinary Medicine Cluj-Napoca. 67(1), 249-255.

30. Rahman MA, Ahmad T, Mahmud S, Hossain MR, Barman NC, Uddin ME, and Ahmed R. (2019) Isolation, identification and antibiotic sensitivity pattern of Salmonella spp. from locally isolated egg samples. Am. J. Pure Appl. Sci., 1(1), 1-11. https://doi.org/10.34104/ajpab.019.019111

31. Ramaswamy, S., McBride, J.L. and Kordower, J.H., (2007). Animal models of Huntington's disease. Ilar Journal, 48(4), 356-373.

32. Rosenstiel, P., Gharavi, A., D'Agati, V. and Klotman, P., (2009). Transgenic and infectious animal models of HIV-associated nephropathy. Journal of the American Society of Nephrology, 20(11), 2296-2304.

33. Rossana, D. and Cristina, G., (2010). Towards the recombinant drug. Eur. Mol. Biol. Lab., 4, 34-35.

34. Schenk, D., (2002). Amyloid- $\beta$ immunotherapy for Alzheimer's disease: the end of the beginning. Nature Reviews Neuroscience, 3(10), 824-828.

35. Sharif IH, Haque MA, Jamal MAHM, and Uddin ME. (2019). Assessment and Biomonitoring of the Effect of Rapeseeds Oil on Wister Rat Organs. Am. J. Pure Appl. Sci., 1(4), 20-29. https://doi.org/10.34104/ajpab.019.0192029

36. Shahen MZ, Mahmud S, Imran MAS, Islam MM, Islam MR, Uddin ME and Alam MS. (2019). Effect of antibiotic susceptibility and inhibitory activity for the control of growth and survival of microorganisms of extracts of Calendula officinalis, Eur. J. Med. Health Sci. 1(1), 1-9. https://doi.org/10.34104/ejmhs.019

37. Snaith, M.R. and Törnell, J., (2002). The use of transgenic systems in pharmaceutical research. Briefings in Functional Genomics, 1(2), 119-130.

38. Spires, T.L. and Hyman, B.T., (2005). Transgenic models of Alzheimer's disease: learning from animals. Neuro Rx, 2(3), 423-437.

39. Srinivasan, K. and Ramarao, P., (2007). Animal model in type 2 diabetes research: An overview. Indian Journal of Medical Research, 125(3), 451.

40. Stewart Jr, C.N., (2004). Genetically modified planet: environmental impacts of genetically engineered plants. Oxford University Press. ISBN: 0-19-515745-1.

41. Uddin ME, Maitra P, Faruquee H. M., Alam MF. (2014). Isolation and characterization of proteases enzyme from locally isolated Bacillus sp. American J. of Life Sciences, 2(6): 338-344. https://doi.org/10.11648/j.ajls.20140206.12

42. Wessells, M.G., (2009). Do no harm: toward contextually appropriate psychosocial support in international emergencies. American psychologist, 64(8), 842.

43. Wheeler, M.B., (2007). Agricultural applications for transgenic livestock. Trends in Biotechnology, 25(5), 204-210.

44. Woods, N.B., Bottero, V., Schmidt, M., Von Kalle, C. and Verma, I.M., (2006). Therapeutic gene causing lymphoma. Nature, 440(7088), 1123-123.

Citation: Sarkar C, Jamaddar S, Zulfiquar TN, and Mondal M. (2020). Boon and bane of transgenic animal: a brief review. Eur. J. Med. Health Sci., 2(2), 21-27.

https://doi.org/10.34104/ejmhs.020.21027 (c) † 